\title{
Comparative Study of Consumer Protection in India as Per UN Guidelines
}

\author{
Lalita Dhingra \\ Assistant Professor D.A.V.Centenary College Faridabad
}

\begin{abstract}
This paper attempts to present the state of affairs of consumer protection in India by inspecting the current status with respect to UN guidelines for consumer protection. The paper throws light on the present scenario by conferring some data and headlining the problems. It inspects that the legal and policy framework in India is adequately good as per the measures stated by UN guidelines (Consumers International), but when it comes to implementation, the scenario is not up to the mark. It concludes with some recommendations that might further improve the consumer protection in India.
\end{abstract}

Keywords: consumer protection, consumer education, consumer protection act, consumer rights, implementation.

\section{Objective:}

The objective of this paper is to present the plight of Consumer Protection Act by analysing its current status with reference to Consumers International or as per UN guidelines. It states the major deviations between the consumer protection framework and its application, their drawbacks and the reasons behind it. It also highlights the need of Consumer Education and the urgency of initiating the Consumer Movements to combat consumer exploitation.

The upcoming concept of industrialisation coupled with globalisation, liberalisation across the nations has empowered the consumers to realise their role in governance and society. An analysis of marketing management has made it clear that consumer is the king pin of the market. The producer should produce goods keeping in mind the requirements of the consumer and satisfy the consumer needs. In a developing country like India where the prevalence of poverty and unemployment is very high and level of literacy is very low, because of which people have to go through bulk of problems, notably in consumer related issues. Unlike in the developed world, consumer such countries lack in promotion of development process.

As we all know, the basic purpose of economic planning is to allocate resources for maximum satisfaction of consumer needs. Ultimately the goods and services produced in any economy are meant for the king of the market i.e. the consumer. In a rational economy, there is this logical, political, and moral force in the proposal that the consumers themselves should have the right to take and make decisions for fulfilling their needs with wise use of resources being allocated. Realising this, the international organisation of consumer unions, now known as Consumers International took the action and under its consistent persuasion, the UN adopted a set of guidelines for the Consumer Protection on April 9, 1985 which were amended in 1999. These guidelines address the consumers keeping in view their needs and interest worldwide by promoting consumer protection and administer the legal framework for government stressing on development and newly independent countries by embellishing and strengthening consumer protection policies and legislation.

Consumer protection is very wide. It includes various rights and various remedies which are available to consumers.

There are three aspects of consumer protection:

$>$ Physical protection

$>$ Protection of economic interest

$>$ Promotion of public interest.

These are not only beneficial for consumers but it is equally important for businessmen also, when Corporate Social Responsibility (CSR) is at its peak of consumer protection. These are as follows:

$>$ Physical safety

$>$ Promotion and protection of consumer's economic interest

$>$ Standards for safety and quality of consumer goods and services.

$>$ Distribution facilities for essential consumer goods and services.

$>$ Measures enabling consumers to obtain redress.

$>$ Education and information programmes

$>$ Promotion of sustainable consumption 
$>$ Measures relating to specific areas like water, food and pharmaceuticals.

As per the above mentioned guidelines, these are adapted into 8 consumer rights by Consumers International:

1. Right to Basic needs

2. Right to Choice

3. Right to Information

4. Right to Safety

5. Right to Consumer Education

6. Right to Redressal

7. Right to Representation

8. Right to Healthy Environment

This paper evaluates the current situation along with these rights and the corresponding drawbacks in its administration. They are as follows:

\section{Basic Needs}

Every citizen has a right to fulfil the basic needs to survive and have dignified living. The basic needs include food, clothing, health care, drinking water, sanitation, shelter, education, energy and transportation. The UN guideline indirectly mentions the right to make basic needs for government to take adequate measures so that consumers can easily access the "basic needs for goods and services." There are 2 goods and 6 services included in the basic needs.

Right to Food

In India, the central government for ensuring food security (Right to Food) introduced Public Distribution System (PDS). Surveys show that on an average $25 \%$ of poor are availing the advantages of PDS. The minor failures of PDS relate to the factors such as low margins of Fair Price Shop owners, which lead to corruption, transportation bottlenecks, timings of the opening of shops are not convenient.

a) Right to basic need

It is an essential need and therefore it comes under 'Right to basic need.' In India the Textile policy, 1981 was introduced for establishing infrastructure for distribution of cloth to weaker sections of the society. The Textile Regulation, 1988 also highlights some of these issues. De-licensing of sector in August 1991 is yet another measure which was taken.

b) Right to Health

National Health Policy and Drug Policy give the synopsis of Right to Health. Since independence, life expectancy at birth has more than doubled, in 1947 it was 30 years and in 1992-96 it was 60 years. The infant mortality rate declined from 134 per 1000 live births to 72 infants per 1000 in 1998.

c) Right to Shelter

In 1988, the government of India approved the National Housing \& Habitat Policy to ensure the Right to Shelter. This policy conceptualised a major shift in government rule from provider to facilitator. Currently the housing scenario is such that $25-50 \%$ of urban population is living in throw-away settlements or slums. In rural areas $75 \%$ of the constructions are semi-permanent in nature.

a) Right to Education

As per the chapter mentioned in Directive Principle of State Policy in the constitution of India. The $83^{\text {rd }}$ Constitutional (Amendment) Act 2000 has made elementary education a fundamental right. Basic and elementary education is compulsory for all children upto 14 years of age and also Adult Education is being promoted.

b) Right to Energy-

The Indian Electricity Act 1910 and Electricity (supply) Act 1948 have been amended to conduct in a new legal administrative and financial environment. State electricity boards have been reorganised and the Central Electricity Regulation Commission and State Regulatory Commission have been set up. Census 1991 states that only about $42 \%$ of household had access to electricity in their households as against $26 \%$ in 1981. The rural urban ratio is quite noticeable. In $19913 / 4^{\text {th }}$ of rural population had access to electricity.

c) Transport-

There is an urgent need to adopt a well integrated transport policy covering roads, railways and water transport. 


\section{Safety}

According to this right the consumers have the right to be protected against the marketing of goods and services which are hazardous to life and property. UN guidelines contemplate two kinds of safety.

$>$ Physical Safety and Standards of safety

$>$ Quality of consumer goods and service

In India there are legislative and administrative provisions concerning this right. Under the constitutions provisions, the most essential one is the Protection of Life \& Personal Liberty (Article 21). Under the legislative provisions, the crucial ones are Prevention of Food Adulteration Act, 1954 and Bureau of Indian Standard Act, 1986.

Even though the categorizing certain products to comply to Indian Standard Institution (ISI) norms and regulations, still many products in the market are still without ISI mark. Infect the product with ISI marks are not adhering to its norms. They are even unaware of whom to approach in case they face any problem regarding safety. Prevailing corruption in the administrative system makes the laws ineffective in many such cases.

\section{Right To Choice}

According to this right every consumer has the right to choose the goods or services of his/her liking. This means an assurance of availability, ability and access to variety of products and services at competitive price and by competitive price we mean just and fair price. UN guidelines deal with economic aspects under its section on promotion and protection of consumer's economic interest.

In India, there are many administrative and legislative measures which guide the consumer with reference to types of goods and the terms \& conditions they should buy. These measures also expound numerous duties and responsibilities for guiding supplies along with penalties/fines for not adhering to it. The considerable legislations are approving MRTP Act 1969, Bureau of Indian Standards Act 1986 and Weight Measure

Act.

For better evolution and advancement in India, enactment of independent regulatory mechanisms in the field of electricity, insurance, telecom etc. should be executed. A new competition law 'Competition Act 2002' has replaced MRTP Act, is being introduced. However, factors like limited information about products, preconceived notions, and absence of effective regulatory mechanism cease the consumers to follow and take actions.

\section{Right To Information}

According to this right the consumer has the right to get information about the quality, quantity, purity, standard and price of goods and services so as to protect himself against the abusive trade practices and making right decisions. Also, consumers should have the right to access information regarding public affairs as well as those which are handled by government and its agencies. Right to Information Act 2005 has been introduced for the same. Adding further, provisions regarding the Right to Information are these under the Consumer Protection Act 1986, Bureau of Indian Standard Act 1986, MRTP Act 1969, Standard of Weight and Measures Act 1976.The department of consumer affairs has taken certain steps to provide information to the public. For promotions, advertisings with "JAAGO GRAHAK JAAGO!" as an intensive multimedia consumer campaign are being telecasted regularly to make the consumers aware of their rights and duties especially in rural areas. National Consumer Helpline is started for easy filing of complaints. The inter play of many institutions/ministries with little co-ordination is the major hurdle in the way of implementation of these law.

\section{Consumer Protection}

According to this right, it is the right of consumer to acquire the knowledge and skills to be informed to customers. Along with the aim to literate the consumers to know their rights and take actions, this right also assures that illiterate consumer can seek information about the existing acts and agencies that are being set up for their protection.

At present there isn't any definitive policy in India concerning consumer education. But, the government of India has included consumer education in the school curriculum and various university colleges. The NCERT is working on introducing consumer education in the syllabus. The IGNOU has devised a syllabus for distant education on consumer protection as a separate course. Likewise, Government of India by implementing Consumer Welfare Fund has designed provisions to fund and promote consumer education programme initiated by consumer groups of state government despite provision taken by government of India and consumer organisations, still masses are unaware or partially aware about legislations and implementation of consumer protection mechanism. 


\section{Right To Redressal}

This right includes right to be compensated for misrepresentation of unsafe/deficient goods or unsatisfactory services and availing the acceptable forms of legal aid or redressals for small claims. In India, the Consumer Protection Act was enacted in 1996 with definitive aim for promoting consumers rights and implementing a cheap, speedy and simple redressal to consumer disputes. Three tier Quasi-Judicial Machinery is set up at each district, state and national levels called District Forums, State Consumer Redressal commission respectively. At present, there are 569 district forums, 33 state commissions with apex as a National Consumer Dispute Redressal Commission having office at Janpath Bhawan, New Delhi. This has provided numerous benefits to the consumers. Despite the establishment of such comprehensive law, the scenario of consumer redressal in India is constrained with complications like non-compliance with order, delays in judgement etc. However, the current scene regarding this certainly shows a tremendous improvement as compared from past situations.

\section{Right To Representation}

According to this right, the consumer has the right to represent himself or to be heard or to advocate his interest. In case a consumer has been exploited or has any complaint against the product or service then he has the right to be heard and be assured that his/her interest would receive due considerations. The UN guidelines have formulated several measures with respect to the Right to Representation. Firstly government should encourage the development of independent consumer groups for presenting the views in the decision making process.

In India, government has set up Parliament Commission and representation mechanism in various departments. Furthermore, the directorate of Public Grievances handles complaint that is addressed to the central government. Thirdly, any individual or group can seek remedies through representation by filing written petitions in the Supreme Court or high court.

The freedom of Information Bill 2000 has been implemented by parliament to facilitate the process of Representation. On a whole, the major issue associated with representation is the corruption in the system, which leads to delays in getting justice. Also there is lack of effective co-ordination between consumer organisations to ensure thorough implementation.

\section{Healthy Environment}

According to this right, the consumer and all the citizens have the right to be protected against the environmental pollution and environmental degradation. This right insists on providing a pollution free, tension free and healthy environment for today's and future generations' i.e. sustainable development. As per the UN guidelines government must adopt measures to use, store and production of pesticides and chemicals. The concept of sustainable development and consumption was also included in it. This is now listed as a consumer right.

Introduction of Environment Act 1986 provides the instructions for management of hazardous wastes etc. for example - safety reports, safety audit etc. It also includes pollution of water, air and soil. Though these laws have been introduced but they are not implemented effectively. Multiplicity of law is the major reason for this, which further adds to multiplicity of administration, corruption and lack of resources to implement the laws faithfully.

Lack of awareness among consumers regarding hazardous use of pesticides and chemicals and also ineffective training of people broadens the problem further.

In the context of Sustainable Consumption, promotion by government, through indirect measures The Biological Diversity Bill has been introduced to secure the conservation, sustainable use of equitable share in benefits arising out of the use of such biological resources.

\section{Conclusion}

As seen from the above written content and data, it is clearly evident that in India it is not the legislative part that is inadequate in administering the consumer protection mechanism of rights and laws. The actual challenge lies in strengthening the administrative mechanism in achieving such measures plus providing incentives for the officials to perform their duties without feeling handicapped due to lack of resources. Most importantly government should revitalize the Public Distribution System (PDS) in India, which should assure that the people Below Poverty Line (BPL) get the maximum gains from PDS. Punishment and fines to food adulterers, hoarders, black marketers of necessary consumer goods and services and severe penalties should be imposed, that it acts as a big discouragement for such criminals or defaulters. All in all other basic needs like health, education etc. are mandatory but unless until consumers will be motivated and empowered to take initiative in the development process, the whole bulk of rights, laws and 
programmes which are implemented by the government cannot succeed. The issue which is being most critical is Consumer Education. Even though the Department of Consumer Affairs are taking major steps but as we can see the outcomes are not that favourable. A strong and sturdy blow of Consumer Movement is the hour of the need.

\section{References}

[1]. Planning Commission, Government of India, National Human Development Report, 2001.

[2]. Consumer Unity Trust Society, 2001- State of the Indian Consumer

[3]. United Nations, (1985/1999), Guidelines for Consumer Protection, April 9, 1985

[4]. (General Assembly Resolution No.: 39/248), revised in 1999.

[5]. Business Studies, M.C. Sharma. 